\title{
APLIKASI STEGANOGRAFI UNTUK PENYISIPAN PESAN
}

\author{
Siti Rohayah ${ }^{1}$, Ginanjar Wiro Sasmito ${ }^{2}$, Oman Somantri ${ }^{3}$ \\ D3 Teknik Komputer ${ }^{1}$, D4 Teknik Informatika ${ }^{2,3}$ \\ Politeknik Harapan Bersama Tegal
}

\begin{abstract}
Abstrak
Dengan semakin berkembangnya teknologi informasi dan telekomunikasi, maka perhatian pada tingkat keamanan akan menjadi semakin penting. Salah satunya adalah tingkat kemanan penyisipan data atau informasi. Peningkatan keamanan penyisipan data dapat dilakukan dengan menggunakan Steganografi. Steganografi adalah teknik menyembunyikan pesan ke dalam sebuah media digital. Media digital yang dapat digunakan adalah teks, gambar, suara, dan video. Penelitian ini membahas tentang penerapan Steganografi untuk penyisipan pesan. Jenis pesan yang dapat disisipkan adalah pesan teks dengan format ( $p d f$ dan doc), pesan gambar dengan format (jpg, png, gift dan bmp), pesan suara dengan format (mp3, wav dan wma), serta pesan video dengan format (3gp). Aplikasi ini dikembangkan dengan menggunakan bahasa pemrograman Java dalam platform IDE NetBeans 6.8. Aplikasi yang dibangun dengan menggunakan bahasa pemrograman Java tersebut dapat menyisipkan pesan. Pesan yang dapat disisipkan antara lain pesan teks dengan format pdf dan doc, pesan gambar dengan format jpg, png, gift dan bmp, pesan suara dengan format $\mathrm{mp} 3$, wav dan wma, serta pesan video dengan format $3 g p$.
\end{abstract}

Kata Kunci : Steganografi, Penyisipan Pesan

\section{PENDAHULUAN}

Dalam era globalisasi seperti sekarang ini, dibutuhkan suatu komunikasi tanpa batas. Dengan adanya jaringan global seperti internet, maka komunikasi tanpa batas dapat diakses kapanpun, di manapun, dan oleh siapapun. Oleh karena itu dibutuhkan suatu tingkat keamanan data agar data tidak dapat diakses oleh sembarang orang dan kerahasiaannya dapat terjamin.

Salah satu hal yang dapat dilakukan untuk mengatasi situasi tersebut adalah dengan mengembangkan suatu aplikasi yang mampu menyamarkan pesan tersebut pada suatu media yang dapat diakses oleh setiap orang. Teknik ini disebut Steganografi. Steganografi berasal dari bahasa Yunani yang berarti "tulisan tersembunyi". 
Menurut Munir (2004) bahwa Steganografi didefinisikan sebagai ilmu dan seni untuk menyembunyikan pesan rahasia (hiding message) sedemikian sehingga keberadaan (eksistensi) pesan tidak terdeteksi oleh indera manusia. Media yang digunakan umumnya merupakan suatu media yang berbeda dengan media pembawa informasi rahasia, disinilah fungsi dari teknik steganography yaitu sebagai teknik penyamaran menggunakan media lain yang berbeda sehingga informasi rahasia dalam media awal tidak terlihat secara jelas.

Dengan perkembangan teknologi modern, pesan teks, gambar, suara dan video dapat disembunyikan di balik citra (image), suara, teks, dan video. Cara ini sangat berguna jika digunakan pada Steganografi yang berbasis komputer, karena banyak format file digital yang dapat dijadikan media untuk menyembunyikan pesan. Dalam penelitian ini teknik penyembunyian pesan menggunakan format gambar suara, teks dan video. Adapun metode yang digunakan dalam menyembunyikan pesan pada media digital tersebut berbeda-beda, diantaranya: LSB (Least Significant Bit), algoritmaand transformation, redundant pattern encoding, danspread spectrum.Berdasarkan pada latar belakang masalah tersebut, maka Aplikasi Steganografi Untuk Penyisipan Pesan sangat dibutuhkan karena keberadaan pesan hanya diketahui oleh pengirim dan penerima dan tidak mudah di hack oleh orang yang tidak berhak untuk mengetahuinya. Tujuan penelitian ini yaitu menghasilkan aplikasi Steganografi untuk penyisipan pesan.

\section{Steganografi}

\subsection{Pengertian Steganografi}

Kata Steganografi (steganography) berasal dari bahasa Yunani yang terdiri dari kata steganos yang artinya tersembunyi dan graphien yang artinya menulis, sehingga bisa diartikan sebagai tulisan yang tersembunyi. Dapat disimpulkan bahwa, Steganografi adalah ilmu yang mempelajari teknik pengembangan pesan rahasia di dalam pesan yang lainnya, sedemikian rupa sehingga orang lain tidak akan tahu bahwa terdapat pesan rahasia di dalam pesan yang mereka baca (Schneier, 1996).

\subsection{Penyisipan Pesan}

Untuk melakukan penyisipan pesan baik itu pada pesan teks, gambar, suara dan video dibutuhkan masukan berupa file digital yang akan disisipkan pesan, pesan yang akan disisipkan (message), dan kunci (key).

Menurut Alatas, 2009 bahwa ada beberapa contoh media penyisipan pesan rahasia yang digunakan dalam teknik Steganography antara lain adalah:

a. Teks

Dalam algoritma Steganography yang menggunakan teks sebagai media penyisipannya biasanya digunakan teknik NLP (Natural Language Processing) sehingga teks yang telah disisipi pesan rahasia tidak akan mencurigakan untuk orang yang melihatnya.

b. Gambar

Format gambar paling sering digunakan, karena format ini merupakan salah satu format file yang sering dipertukarkan dalam dunia internet. Alasan lainnya adalah banyaknya tersedia algoritma Steganography untuk media penampung yang berupa citra.

c. Suara

Format suara sering dipilih karena biasanya berkas dengan format ini berukuran relatif besar. Sehingga dapat menampung pesan rahasia dalam jumlah yang besar pula. 


\section{d. Video}

Format video memang merupakan format dengan ukuran file yang relatif sangat besar namun jarang digunakan karena ukurannya yang terlalu besar sehingga mengurangi kepraktisannya dan juga kurangnya algoritma yang mendukung format ini.

Steganografi berfungsi untuk menyembunyikan keberadaan pesan dan dapat dianggap sebagai pelengkap dari kriptografi yang bertujuan untuk menyembunyikan isi pesan. Berbeda dengan kriptografi dalam Steganografi pesan disembunyikan sedemikian rupa sehingga pihak lain tidak dapat mengetahui adanya pesan rahasia. Pesan rahasia tidak diubah menjadi karakter 'aneh' seperti halnya kriptografi. Pesan tersebut hanya disembunyikan ke dalam suatu media berupa gambar, teks, musik, atau media digital lainnya dan terlihat seperti pesan biasa.

Untuk memudahkan dalam proses penyembunyian pesan teks ke dalam image, maka dirancang suatu aplikasi Steganografi untuk penyisipan pesan. Aplikasi dirancang dengan tiga proses yaitu mengambil image, menambahkan pesan ke dalam image (encode image) dan menampilkan pesan rahasia (extract) dalam image

\subsection{Pengertian Aplikasi}

Menurut Pramana, 2012 aplikasi adalah satu unit perangkat lunak yang dibuat untuk melayani kebutuhan akan beberapa aktivitas seperti sistem perniagaan, game, pelayanan masyarakat, periklanan dan hampir semua proses kegiatan.

Yang dimaksud perangkat lunak aplikasi adalah suatu sub kelas perangkat lunak komputer yang memanfaatkan kemampuan komputer langsung untuk melakukan suatu tugas yang diinginkan pengguna. Biasanya dibandingkan dengan perangkat lunak sistem yang mengintegrasikan berbagai kemampuan komputer, tapi tidak secara langsung menerapkan kemampuan tersebut untuk mengerjakan suatu tugas yang menguntungkan pengguna. Contoh utama perangkat lunak aplikasi adalah pengolah kata, lembar kerja, dan pemutar media

\section{Analisa dan Perancangan Sistem}

Permasalahan yang berkaitan dengan aplikasi Steganografi untuk penyisipan pesan yaitu pada penyisipan pesan pada teks, gambar, suara dan video. Adapun penyisipan pada pesan teks berformat (pdf dan doc), pada file gambar berformat (jpg, png, bmp dan gift), pada file suara berformat (mp3, wav dan wma), serta pada file video berformat 3gp.

Dalam pengumpulan data aplikasi ini menggunakan cara studi pustaka yakni mengumpulkan data dan informasi dari buku teks dan internet yang berkaitan dengan pembuatan aplikasi Steganografi tersebut.

Untuk keamanan pesan, Steganografi memiliki tiga cara kerja yaitu hidden text, algoritma penyisipan dan algoritma pendeteksian. Sesuai dengan tujuan Steganografi itu sendiri yaitu menyembunyikan isi pesan, maka dibutuhkan sebuah aplikasi Steganografi untuk penyisipan pesan. 


\subsection{DFD Level 0}

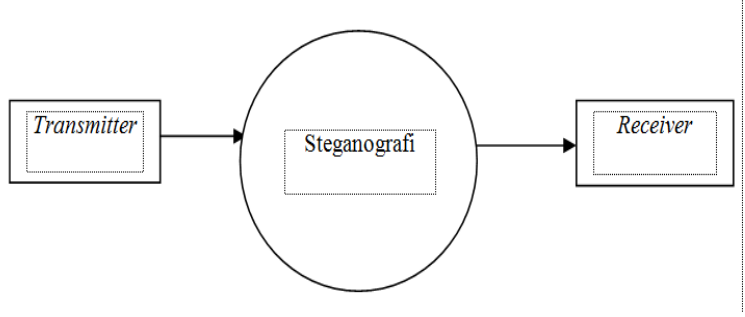

Gambar 1. DFD Level 0

\subsection{DFD Level 1}

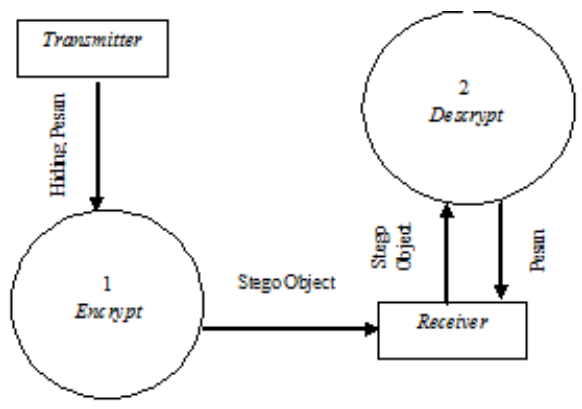

Gambar 2. DFD Level 1

\subsection{Diagram Alir}

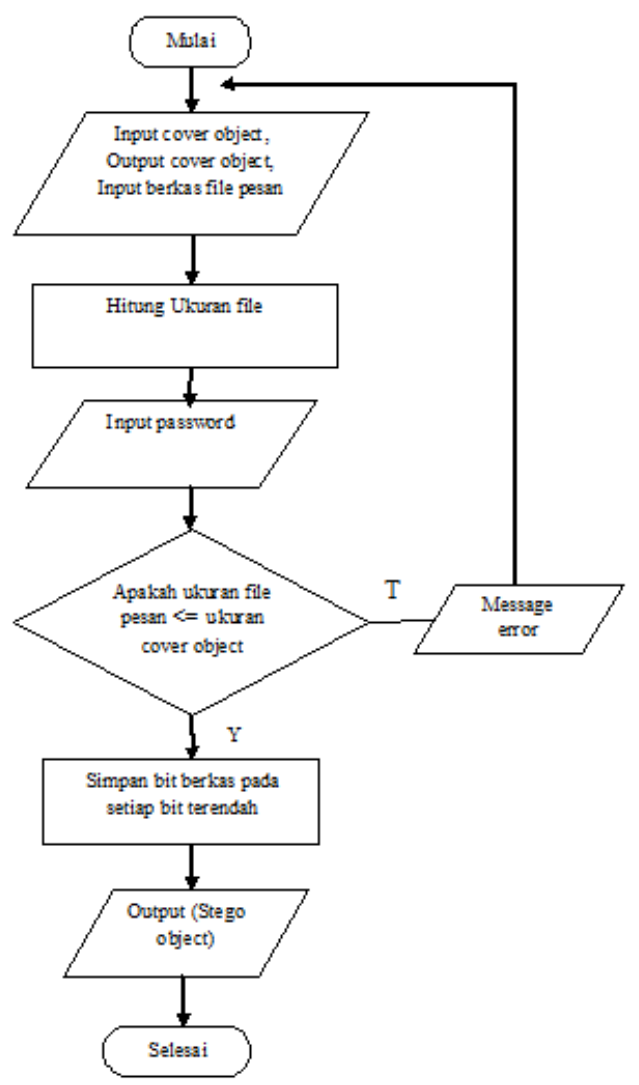

Gambar 3 Flowchart Penyisipan Pesan 


\section{Implementasi}

Tahap implementasi ini mengacu pada dua sub sistem utama sistem steganography, yaitu penyisipan dan pengekstrakan.

\subsection{Tampilan Program}

Tampilan pada program yang diimplementasikan dapat dilihat seperti gambar berikut ini:

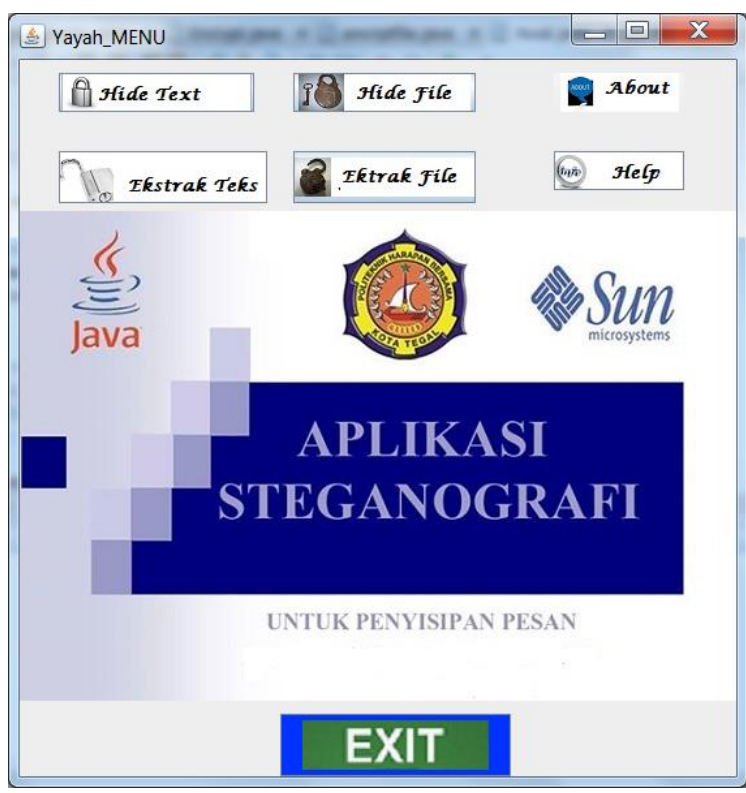

Gambar 4 Menu

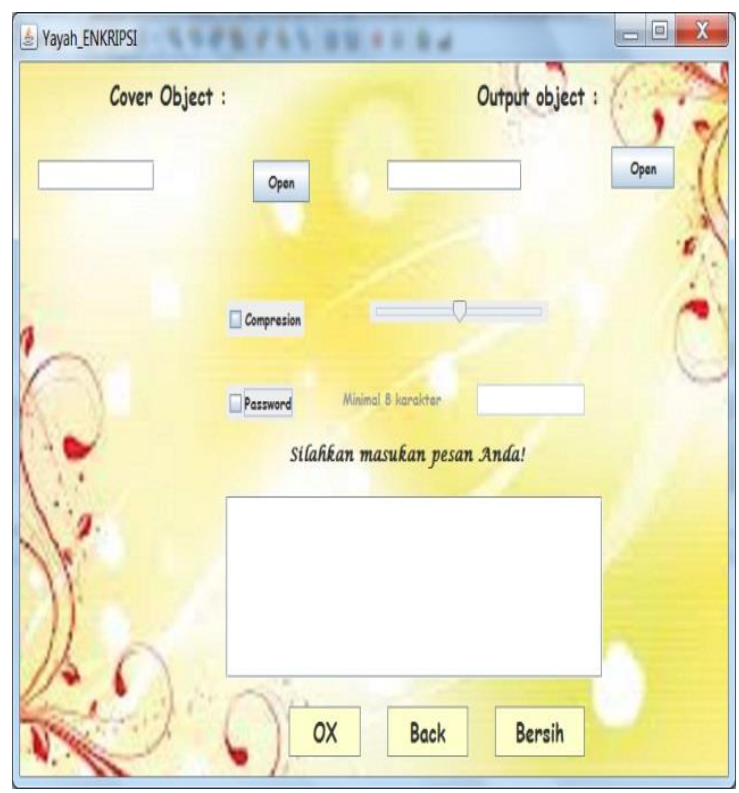

Gambar 5 Form Hide Text

\subsection{Uji Coba dan Analisa}

Pengujian dilakukan berdasarkan spesifikasi aplikasi dan juga terhadap ketahanan data. Pengujian berdasarkan spesifikasi aplikasi meliputi pengujian kesesuaian proses, kesesuaian data, dan kualitas pesan. Sedangkan pengujian ketahanan data hanya dilakukan terhadap berkas stego object berbentuk suara. Untuk melakukan pengujian, digunakan beberapa berkas pesan, seperti pesan teks berformat (pdf, dan doc), pesan gambar berformat (jpg, png, gift dan bmp), pesan suara berformat (mp3, wav dan wma) serta pesan video berformat (3gp), dengan spesifikasi seperti tabel berikut:

TABEL 1. SPESIFIKASI PESAN TEKS YANG DIUJI

\begin{tabular}{|r|l|r|}
\hline No & \multicolumn{1}{|c|}{ Nama-File-Teks $\propto$} & Ukwan-File $\alpha$ \\
\hline $1 \propto$ & pcd.pdf $\propto$ & $1134 \cdot \mathrm{Kb} \propto$ \\
\hline $2 \propto$ & suara.pdf $\propto$ & $108 \cdot \mathrm{Kb} \propto$ \\
\hline $3 \propto$ & Steg.pdf $\propto$ & $296 \cdot \mathrm{Kb}$ \\
\hline
\end{tabular}


TABEL 2. SPESIFIKASI GAMBAR TEKS YANG DIUJI

\begin{tabular}{|c|c|c|}
\hline Noc & Nama'File $\cdot$ Gambaro & Ukuran'Filea \\
\hline 10 & images.jpga & $10 \mathrm{~Kb}$ \\
\hline 20 & USER.png & $41 \mathrm{~Kb}$ \\
\hline 30 & 06.gifa & $25 \mathrm{~Kb} \mathrm{c}$ \\
\hline 40 & GAMBAR.bmpo & $636 \cdot \mathrm{Kb} \mathrm{c}$ \\
\hline
\end{tabular}

TABEL 3. SPESIFIKASI SUARA YANG DIUJI

\begin{tabular}{|c|c|c|c|}
\hline No & Nama'File $\cdot$ Suaraa & Durasio & Ukwan-Filea \\
\hline 10 & rindu.mp3a & $00.04 .44 \alpha$ & $4441 \mathrm{~Kb}$ \\
\hline 20 & suaraAir.wavo & 00.00 .05 a & $485 \cdot \mathrm{Kb}$ \\
\hline $3 \alpha$ & suaraAzan.wmad & $00.03 .12 \alpha$ & $3034 \mathrm{~Kb}$ क \\
\hline
\end{tabular}

TABEL 4. SPESIFIKASI VIDEO YANG DIUJI

\begin{tabular}{|l|l|l|l|}
\hline No & Nama-File $\cdot$ video & Durasio & Ukman'File \\
\hline $1 \propto$ & rindu.3gp $\propto$ & $00.00 .26 \propto$ & $408 \cdot \mathrm{Kb} \propto$ \\
\hline $2 \propto$ & Naudzubilah.3gp $\propto$ & $01.09 .26 \propto$ & $85.187 \cdot \mathrm{kb} \propto$ \\
\hline
\end{tabular}

TABEL 5. HASIL PENGUJIAN BERDASARKAN SPESIFIKASI APLIKASI

\begin{tabular}{|c|c|c|c|c|c|c|c|}
\hline No. & $\begin{array}{l}\text { Nama Cover } \\
\text { Object }\end{array}$ & File Pesan & $\begin{array}{l}\text { Peny- } \\
\text { Isipan }\end{array}$ & $\begin{array}{l}\text { Nama } \\
\text { Stege } \\
\text { Object }\end{array}$ & Ekstraksi & $\begin{array}{l}\text { Kesesuai } \\
\text { an Data }\end{array}$ & $\begin{array}{c}\text { Kualitas } \\
\text { Pesan }\end{array}$ \\
\hline 1 & pcd.pdf & GAMBAR.bmp & Berhasil & Uji1.pdf & Berhasil & Sesulai & Sama \\
\hline 2 & Suarapdf & GAMBAR.bmp & Berhasil & updf & Berhasil & Sesuai & Tidak sama \\
\hline 2 & Steg.docx & tugas1.docx & Berhasil & Uji2.docx & Berhasil & Sesuai & Sama \\
\hline 3 & GAMBAR.bmp & suaraAirmp 3 & Berhasil & Uji3.bmp & Berhasil & Sesuai & Tidak Sama \\
\hline 4 & 06.gif & tugas1.docx & Berhasil & Uji4.gif & Berhasil & Sesuai & Sama \\
\hline
\end{tabular}

\section{Kesimpulan}

Berdasarkan analisis dan pembahasan yang dilakukan dapat diambil kesimpulan sebagai berikut:

a. Pada penerapan aplikasi Steganografi tersebut dapat menyisipkan pesan ke dalam media digital.

b. Pada aplikasi Steganografi ini dapat memudahkan pengguna dalam menyisipkan pesan. Penyisipan dan ekstraksi pesan dapat dilakukan dengan baik, jika ukuran file cover object lebih besar daripada ukuran file pesan yang disisipkan. 


\section{DAFTAR PUSTAKA}

Alatas Putri, M. Subali, "Implementation Technique With Steganography LSB Method in Digital Images". Undergraduate Program, Faculty of Computer Science, Gunadarma University, 2009

Anneria, Yulie Sinaga, "Program Steganalisis Metode LSB pada Citra dengan Enchaned LSB, Uji Chi Squere dan RS-Analisis", 2007

Bender, dkk., 1996, Techniques For Data Hiding, IBM Systems Journal

Dedy Irawan, J and Adriantantri, E. 2010. "Steganografi Untuk Menyembunyikan Suara Dengan Smart Card sebagai Kunci Enkripsi”. Jurnal Elektro ELTEK. 1(1). 43-49

Helyda Yusuf, Yesrani. 2011. "Implementasi Aplikasi Steganografi Dengan Menggunakan EURA Steganographer, JPHide and Seek, Steganog, dan Steganomagic”. STMIK AMIKOM: Laporan Tidak diterbitkan

Jiri, Fridrich. 2003. Application of Data Hiding in Digital Images.[Online]. Tersedia: http://ssie.binghamton.edu/ jirif [19 Agustus 2003]

Jiri, Fridrich.1998.Application of Data Hiding in Digital Images.[Online]. Tersedia: http://ssie.binghamton.edu/ jirif, 1998 h.4.

Leman.1998.Metodologi Pengembangan Sistem 